\title{
PENGARUH EKSTRAK ETANOL DAUN TAPAK DARA (Catharanthus roseus L.) DAN KOLKISIN TERHADAP PERKECAMBAHAN BIJI CABAI RAWIT HIBRIDA (Capsicum annuum)
}

\author{
Purwanti Pratiwi Purbosari ${ }^{1}$ \\ Etika Dyah Puspitasari \\ ${ }^{1,2}$ Universitas Ahmad Dahlan, Yogyakarta
}

Email: ${ }^{1}$ Purwanti.purbosari@pbio.uad.ac.id, ${ }^{2}$ etika.puspitasari@pbio.uad.ac.id

\begin{abstract}
Catharanthus roseus L. contain vinca alkaloid compounds which have anti-mitotic effect like colchicine. The application of Catharanthus roseus L. extract and colchicine in many plants was usually done by soaking the plant seeds. The aim of this research was to analyze the effect of ethanolic leaf extract of Catharanthus roseus L. and colchicine on seed germination of Capsicum annuum. 20 Seeds of Capsicum annuum were soaked for $24 \mathrm{~h}$ in ethanolic leaf extract of Catharanthus roseus $L$. $(0,05 \%, 0,1 \%$ dan 0,5\%), colchicine $(0,05 \%, 0,1 \%$ dan $0,5 \%)$ and water as control. Seed germination percentage was observed and plant height was measured after 30 days. The 0,5\% leaf extract and 0,5\% colchicine caused the lowest germination percentage. The 0,5\% leaf extract caused the lowest average plant height. Based on ANOVA and Tukey's HSD test, soaked in 0,5\% ethanol leaf extract treatment was significantly different with other treatments (signification 95\%)
\end{abstract}

Keywords: Capsicum annuum, Catharanthus roseus L, colchicine, Germination

Tanaman tapak dara bahwa daun tapak dara mengandung (Catharanthus roseus L.) merupakan tanaman yang banyak tumbuh di Indonesia. Tanaman ini tumbuh liar maupun dibudidayakan sebagai tanaman hias. Berbagai penelitian telah dilakukan untuk mengkaji kandungan dan manfaat dari tanaman tapak dara, diantaranya tanaman tapak dara dilaporkan memiliki efek antihiperglikemi (Nammi dkk., 2006), efek antidiabetes dan mengurangi stres oksidatif (Singh dkk., 2001), serta efek antibakteri (Kabesh dkk., 2015).

Analisis Fitokimia terhadap ekstrak daun tapak dara menunjukkan alkaloid, terpenoid, fenol, tanin, saponin, quinin, dan sterol (Kabesh dkk., 2015). Jenis alkaloid yang terkandung di dalam tanaman tapak dara diantaranya adalah vincristin dan vinblastin yang terkenal memiliki efek anti kanker (Iskandar \& Iriawati, 2015). Selain vincristin dan vinblastin, pada tanaman tapak dara juga terkandung alkaloid lain, yaitu vinorelbin dan vindesin (Moudi dkk., 2013). Vincristin, vinblastin, vinorelbin dan vindesin yang terkandung dalam tanaman tapak dara disebut sebagai vinca alkaloid dan merupakan agen antimitotik. Alkaloid 
tersebut diduga memiliki efek seperti kolkisin yang dapat menggandakan kromosom.

\section{Beberapa}

melakukan aplikasi pemberian ekstrak tanaman tapak dara dan kolkisin untuk melihat efek penggandaan kromosom terhadap tanaman dengan cara merendam biji tanaman di dalam ekstrak tapak dara tersebut maupun di dalam larutan kolkisin. Beberapa diantaranya adalah perendaman biji Eucalyptus pellita $\mathrm{F}$. Muell. menggunakan ekstrak daun tapak dara (Daryono dkk. 2012), perendaman biji semangka menggunakan kolkisin (Citrullus lanatus (Thunb.) Matsum et Nankai) (Rosmaiti \& Dani, 2015), dan perendaman biji zaitun (Olea europaea) (Sirojuddin, dkk 2017). Akan tetapi efek dari pemberian ekstrak daun tapak dara dan kolkisin belum diketahui terhadap keberhasilan perkecambahan tanaman, khususnya cabai rawit hibrida (Capsicum annuиm) yang merupakan tanaman budidaya yang banyak ditanam masyarakat. Keberhasilan perkecambahan adalah hal yang penting terutama pada tanaman budidaya. Penelitian ini bertujuan untuk menganalisis pengaruh ekstrak daun tapak dara (Catharanthus roseus L.) dan kolkisin terhadap perkecambahan biji cabai rawit hibrida (Capsicum annuum).

\section{METODE}

Jenis penelitian ini adalah penelitian eksperimen dengan konsentrasi ekstrak etanol daun tapak dara dan konsentrasi kolkisin yang berbeda digunakan sebagai perlakuan. Percobaan menggunakan rancangan acak lengkap, terdapat tiga kali ulangan untuk masing-masing perlakuan. Penelitian dilaksanakan pada bulan Mei 2018 hingga Juli 2018. Benih cabai rawit yang digunakan adalah benih cabai rawit hibrida (Capsicum annuum) Dewata F1. Tahap persiapan meliputi pembuatan larutan ekstrak etanol daun tapak dara (Catharanthus roseus L.) dan pembuatan larutan kolksin masing-masing dengan konsentrasi $0,05 \%, 0,1 \%$ dan $0,5 \%$. Metode ekstraksi etanol $96 \%$ digunakan untuk membuat ekstrak etanol daun tapak dara. Ekstrak kental daun tapak dara yang didapat selanjutnya dilarutkan menggunakan akuades hingga didapatkan konsentrasi ekstrak $0,05 \%, 0,1 \%$ dan 0,5\%. Dalam pembuatan larutan kolkisin, aquades ditambahkan ke dalam kolkisin cair hingga didapatkan larutan kolkisin dengan konsentrasi $0,05 \%, 0,1 \%$ dan $0,5 \%$.

Masing-masing sebanyak 20 biji cabai rawit hibrida (Capsicum апnиит) direndam dalam larutan ekstrak etanol daun tapak dara $0,05 \%$, $0,1 \%$ dan $0,5 \%$, larutan kolkisin $0,05 \%, 0,1 \%$ dan $0,5 \%$, dan air sebagai kontrol. Perendaman dilakukan selama 24 jam. Biji yang telah direndam dikecambahkan di atas kapas selama 5 hari dan dihitung persentase perkecambahannya. Sebanyak tiga kecambah biji cabai rawit yang berhasil tumbuh dari masing-masing perlakuan selanjutnya 
ditanam di dalam trey berisi media tanam selama 30 hari. Setelah 30 hari tinggi tanaman pada masing-masing perlakuan diukur.

Data perkecambahan biji dianalisis secara kuantitatif sehingga diperoleh persentase biji yang berkecambah. Data tinggi tanaman dianalisis menggunakan Analisis Variansi (ANAVA) dan untuk mengetahui adanya beda nyata antar perlakuan digunakan uji Tukey HSD pada taraf signifikansi 95\%. Selanjutnya data perkecambahan biji dan tinggi tanaman dianalisis korelasinya menggunakan Spearman Correlation $(\alpha 0,05)$.

\section{HASIL DAN PEMBAHASAN}

Tanaman tapak dara selain berpotensi memiliki manfaat sebagai antihiperglikemi, antikanker dan antidiabetes, tanaman ini juga diduga memiliki efek antimitosis seperti kolkisin. Pengaplikasian ekstrak tanaman tapak dara banyak dilakukan dengan cara perendaman terhadap biji tanaman yang ingin dilipatgandakan kromosomnya. Begitu pula dalam pengaplikasian larutan kolkisin terhadap tanaman.

Dalam penelitian ini, sebanyak 20 biji cabai rawit hibrida (Capsicum annuum) direndam dalam larutan ekstrak etanol daun tapak dara $0,05 \%, 0,1 \%$ dan $0,5 \%$, larutan kolkisin $0,05 \%, 0,1 \%$ dan $0,5 \%$, serta air sebagai kontrol. Dari hasil penelitian diketahui bahwa persentase perkecambahan terendah didapatkan dari biji cabai rawit hibrida yang direndam dalam larutan ekstrak etanol daun tapak dara $0,5 \%$ dan kolkisin $0,5 \%$, yaitu sebesar $85 \%$ seperti yang disajikan pada Tabel 1 .

Tabel 1. Perkecambahan biji cabai rawit hibrida (Capsicum annuum) dalam berbagai perlakuaan

\begin{tabular}{lcc}
\hline \multicolumn{1}{c}{ Perlakuan } & $\begin{array}{c}\text { Jumlah Biji } \\
\text { Berkecambah }\end{array}$ & $\begin{array}{c}\text { Persen- } \\
\text { tase }\end{array}$ \\
\hline Ekstrak Daun 0,05\% & 19 & $95 \%$ \\
Ekstrak Daun 0,1\% & 18 & $90 \%$ \\
Ekstrak Daun 0,5\% & 17 & $85 \%$ \\
Kolkisin 0,05\% & 19 & $95 \%$ \\
Kolkisin 0,1\% & 19 & $95 \%$ \\
Kolkisin 0,5\% & 17 & $85 \%$ \\
Kontrol Air & 20 & $100 \%$ \\
\hline
\end{tabular}

Rendahnya
perkentase direndam dalam ektrak etanol daun tapak dara $0,5 \%$ dimungkinkan akibat efek alelokemi yang dimiliki daun tapak dara. Junaedi dkk (2006) melaporkan bahwa senyawa metabolit sekunder seperti alkaloid, terpenoid, steroid dan fenolik dapat memiliki aktivitas alelopati. Dengan bertambahnya konsentrasi ekstrak daun tapak dara pada larutan perendaman akan menambah banyaknya senyawa metabolit sekunder dalam larutan tersebut yang berpotensi memiliki aktivitas alelopati sehingga akan berakibat pada penghambatan perkecambahan biji. Hal ini sejalan dengan data yang didapatkan, yaitu semakin tinggi ekstrak tanaman tapak dara yang digunakan dalam perendaman biji cabai rawit menyebabkan persentase perkecambahan biji cabai rawit tersebut semakin berkurang. Hasil ini sesuai dengan penelitian yang 
dilakukan terhadap biji kedelai varietas anjasmoro bahwa semakin tinggi konsentrasi ekstrak etanol daun tapak dara menyebabkan penurunan persentase perkecambahan biji kedelai tersebut (Kusnuriyanti dkk, 2017).

Selain berasal dari ekstrak
etanol daun tapak dara $0,5 \%$, persentase perkecambahan biji cabai rawit terendah juga didapatkan dari biji yang direndam dalam larutan kolkisin 0,5\%, yaitu sebesar $85 \%$. Hal ini dapat disebabkan karena dalam konsentrasi kolkisin yang tinggi, yaitu sebesar $0,5 \%$, senyawa kolkisin meracuni sel-sel biji cabai rawit yang akan berkecambah. Seperti yang dikemukakan oleh Suryo (2007) bahwa kolkisin dalam konsentrasi yang tinggi dapat menyebabkan efek negatif berupa keracunan tanaman. Hasil ini sejalan dengan penelitian yang dilakukan oleh Herman et al. (2013) yang merendam biji kacang hijau (Vigna radiata L.) selama 24 jam di dalam larutan kolkisin $(0,02 \%$, $0,04 \%, 0,06 \%, 0,08 \%$ dan $0.1 \%$ ) bahwa pada konsentrasi kolkisin yang lebih tinggi menyebabkan persentase perkecambahan menurun. Namun perendaman selama 24 jam pada biji kedelai (Glycine $\max$ (L.) Merr.) dalam larutan kolkisin 0,05\%, 0,1\% dan $0,25 \%$ menyebabkan biji kedelai tidak berkecambah. Hal ini menunjukkan bahwa tingkat ketahanan tanaman terhadap penambahan kolkisin berbeda-beda.

Kecambah biji cabai rawit dari masing-masing perlakuan selanjutnya ditanam di dalam tray. Tinggi tanaman yang diukur setelah 30 hst selanjutnya diukur. Hasil pengukuran tersebut disajikan dalam Tabel 2.

Tabel 2. Tinggi tanaman cabai rawit hibrida (Capsicum annuum) setelah 30 hst

\begin{tabular}{lc}
\hline \multicolumn{1}{c}{ Perlakuan } & $\begin{array}{c}\text { Rata-rata Tinggi } \\
\text { Tanaman }(\mathrm{cm})\end{array}$ \\
\hline Ekstrak Daun 0,05\% & $8,96^{\mathrm{bcd}}$ \\
Ekstrak Daun 0,1\% & $8,16^{\mathrm{bc}}$ \\
Ekstrak Daun 0,5\% & $6,42^{\mathrm{a}}$ \\
Kolkisin 0,05\% & $9,86^{\mathrm{de}}$ \\
Kolkisin 0,1\% & $11,12^{\mathrm{e}}$ \\
Kolkisin 0,5\% & $9,12^{\mathrm{cd}}$ \\
Kontrol Air & $7,5^{\mathrm{ab}}$ \\
\hline
\end{tabular}

Keterangan: huruf yang sama pada kolom menunjukkan tidak berbeda nyata pada uji Tukey HSD $\alpha=0,05$

Dari tabel tersebut diketahui bahwa rata-rata tinggi tanaman terendah setelah 30 hst adalah tanaman yang berasal dari biji yang direndam dalam ekstrak etanol daun tapak dara $0,5 \%$, yaitu sebesar 6,42 $\mathrm{cm}$. Setelah dianalisis secara statistik menggunakan uji Tukey HSD didapatkan bahwa perlakuan perendaman biji menggunakan ekstrak etanol daun $0,5 \%$ berbeda nyata dengan perlakuan perendaman ekstrak etanol daun tapak dara $0,01 \%$ dan $0,05 \%$, maupun dengan perlakuan perendaman menggunakan kolkisin pada konsentrasi $0,05 \%, 0,1 \%$ dan $0,5 \%$. Tingginya konsentrasi metabolit sekunder yang terkandung dalam larutan ekstrak daun tapak dara $0,5 \%$ diduga menjadi penghambat pertumbuhan tanaman cabai rawit. Senyawa metabolit sekunder cukup memberikan efek alelopati bagi sel- 
sel tanaman tersebut (Junaedi dkk, 2006) meskipun belum sampai pada efek kematian tanaman.

Tanaman cabai rawit pada perlakuan perendaman larutan etanol ekstrak daun tapak dara konsentrasi $0,05 \%$ memiliki tinggi yang paling maksimal dibandingkan pada konsentrasi ekstrak etanol tapak dara lainnya. Hasil perlakuan ini berbeda nyata berdasarkan uji Tukey HSD jika dibandingkan dengan perendaman pada larutan ekstrak etanol daun tapak dara konsentrasi $0,5 \%$, meskipun tidak berbeda nyata dengan perlakuan pada konsentrasi $0,1 \%$. Diduga konsentrasi $0,05 \%$ adalah konsentrasi ekstrak etanol daun tapak dara yang paling maksimal untuk mempengaruhi penambahan tinggi tanaman cabai rawit hibrida (Capsicum annuum). Penelitian lain pada kedelai anjasmoro menunjukkan bahwa tinggi tanaman kedelai paling maksimal adalah tanaman yang berasal dari biji kedelai yang direndam dalam ekstrak etanol daun tapak dara konsentrasi 0,1\% (Kusnuriyanti dkk, 2017).

Diantara semua perlakuan, rata-rata tinggi tanaman cabai rawit paling maksimal didapatkan dari biji yang direndam pada larutan kolkisin $0,1 \%$, yaitu sebesar $11,12 \mathrm{~cm}$. Hasil perlakuan ini berbeda nyata dengan perlakuan perendaman menggunakan kolkisin $0,5 \%$, ekstrak etanol daun tapak dara pada ketiga konsentrasi, dan perlakuan kontrol. Hasil ini tidak sesuai dengan pernyataan Singh (2016) bahwa secara umum tanaman yang diberi perlakuan kolkisin akan membesar organ-organnya, seperti penambahan diameter batang, namun tinggi tanaman tersebut akan tetap sama atau bahkan lebih kecil dibandingkan tanaman kontrol. Akan tetapi, beberapa penelitian lain juga mendapatkan hasil yang sama dengan penelitian ini, yaitu perlakuan perendaman biji dengan larutan kolkisin akan mengakibatkan tanaman tersebut tumbuh lebih tinggi dari tanaman kontrol. Perlakuan perendaman biji dalam larutan kolkisin $0,2 \%$ selama 12 jam pada tanaman kacang tanah (Arachis hypogaea L.) menghasilkan tanaman yang lebih tinggi dari pada tanaman kontrol, Pada kembang kertas (Zinnia elegans Jaqc.) perlakuan perendaman biji selama 36 jam pada larutan kolkisin $\quad 0,01 \% \quad$ menghasilkan tanaman yang juga lebih tinggi dari pada tanaman kontrol, dan pada kedelai anjasmoro perendaman biji menggunakan larutan kolkisin $0,01 \%$ dan $0,02 \%$ selama 10 jam menghasilkan tanaman yang juga lebih tinggi dari pada tanaman kontrol (Nofitahesti \& Daryono, 2016). Dengan demikian dimungkinkan pengaruh penambahan kolkisin dapat berbeda efeknya pada tiap tanaman. Beberapa tanaman bertambah diameter batangnya namun tinggi tanaman menjadi lebih rendah dibandingkan kontrol, sedangkan tanaman lain bertambah tingginya.

Data

persentase perkecambahan dan tinggi tanaman selanjutnya dianalisis menggunakan Spearman correlation (sig <0,05). Hasil analisis tersebut menunjukkan 
bahwa ada korelasi yang signifikan antara persentase perkecambahan dengan tinggi tanaman. Koefisien korelasi yang dihasilkan sebesar $\mathrm{r}=$ 0,726 menunjukkan bahwa terdapat korelasi yang kuat antara persentase perkecambahan biji dengan tinggi tanaman. Perlakuan yang mengakibatkan persentase perkecambahan terendah juga menyebabkan pertambahan tinggi yang kurang maksimal pada tanaman cabai rawit hibrida (Capsicum annuum).

\section{KESIMPULAN}

Berdasarkan hasil penelitian dapat disimpulkan bahwa biji cabai rawit hibrida (Capsicum annuum) yang direndam dalam ekstrak etanol daun tapak dara $0,5 \%$ dan larutan kolkisin 0,5\% memiliki persentase perkecambahan terkecil, yaitu $85 \%$. Selain itu, biji cabai rawit hibrida yang direndam dalam ekstrak etanol daun tapak dara $0,5 \%$ juga memiliki pertumbuhan yang paling rendah, sedangkan perlakuan perendaman menggunakan kolkisin $\quad 0,1 \%$ menghasilkan tanaman dengan tinggi paling maksimal.

\section{SARAN}

Setelah diketahui pengaruh ekstrak etanol daun tapak dara (Catharanthus roseus L.) dan kolkisin terhadap perkecambahan biji cabai rawit hibrida (Capsicum annum) maka perlu diteliti lebih lanjut pengaruhnya terhadap produktivitas tanaman cabai rawit hibrida tersebut, serta perlu dilakukan analisis kromosomnya untuk mengetahui tingkat ploidi dari tanaman hasil perendaman biji menggunakan ekstrak etanol daun tapak dara dan kolksisin.

\section{UCAPAN TERIMAKASIH}

Ucapan terima kasih kami sampaikan kepada KEMENRISTEK DIKTI yang telah membiayai penelitian ini. Penelitian ini merupakan bagian dari penelitian dengan nomor Kontrak Penelitian 109/SP2H/LT/DRPM/2018 dan Surat Kontrak Pelaksanaan Penelitian Universitas Ahmad Dahlan PDP001/SKPP/III/2018.

\section{DAFTAR RUJUKAN}

Daryono, B.S., Koeswardani, C.A. \& Sunarti, S., 2012. Karakter Kromosom Ekaliptus (Eucalyptus pellita F. Muell.) Hasil Induksi Ekstrak Etanolik Daun Tapak Dara (Catharanthus roseus (L.) G. Don.). Makalah disajikan dalam Seminar Nasional Agroforesti, 2012. pp. 195199

Herman, Malau I.N., dan Roslim D.I. 2013. Pengaruh mutagen Kolkisin pada biji Kacang Hijau (Vigna radiata L.) terhadap jumlah kromosom dan pertumbuhan. Makalah disajikan dalam Seminar Nasional Biodiversitas dan Ekologi Tropika Indonesia (BioETI). pp. 13-20 
Iskandar, N.N. \& Iriawati. 2016. Vinblastine and Vincristine Production on Madagascar Periwinkle (Catharanthus roseus ( L .) G . Don ) Callus Culture Treated with Polethylene Glycol. Makara journal of science, 20(1):7-16

Junaedi, A., Chozin, M. A., \& Kim, K. H. O. 2006. Perkembangan Terkini Kajian Alelopati. HAYATI Journal of Biosciences, 13(2), 79-84.

Kabesh, K., P. Senthilkumar, R. Ragunathan, \& R. Raj Kumar. 2015. Phytocemical Analysis of Catharanthus roseus Plant Extract and Its Antimicrobial Activity. Int. J. Pure App. Biosci, 3 (2):162172

Kusnuriyanti, E., Fatikasari, S., Fitriasari, I., \& Sfofi, M. 2017. Hasil Mutasi Genetik Dengan Ekstrak Etanolik Daun Tapak Dara (Catharanthus roseus (L.) D. Don). Jurnal Wiyata, 4(2): 121-127

Moudi, M., Go, R., Yien, CYS., Nazre, M. 2013. Vinca Alkaloids. Int. Journal of preventive medicine, 4(11): 1231

Nammi, S., Boini, M. K., Lodagala, S. D., \& Behara, B. S. 2006. The juice of fresh leaves of Catharanthus roseus Linn. reduces blood glucose in normal and alloxan diabetic rabbits. BMC Complementary and alternative medicine, 4(3): $2-5$
Nofitahesti, I., dan Daryono, B. S. 2016. Karakter Fenotip Kedelai (Glycine max (L.) Merr.) Hasil Poliploidisasi dengan Kolkisin. Scientiae Educatia, 5(2): 90-98

Sirojuddin, M.R., Rahayu, T., \& Laili, S. 2017. Pengaruh Pemberian Berbagai Konsentrasi Kolkisin dengan Lama Perendaman terhadap Respon Fenotipik Zaitun (Olea Europaea). Biosaintropis (BioscienceTROPIC), 2(2): 36-41

Rosmaiti dan Dani, J. 2015. Pengaruh

Konsentrasi dan Lama Perendaman Kolkisin Pada Benih Semangka (Citrullus lanatus (Thunb.) Matsum. et Nankai) terhadap Keragaman Tanaman. Agrosamudra, 2(2): $10-18$

Singh, R.J. 2016. Plant Cytogenetics Third Edition. New york: CRC press

Singh, S. N., Vats, P., Suri, S., Shyam, R., Kumria, M. M. L., Ranganathan, S., \& Sridharan, K. 2001. Effect of an antidiabetic extract of Catharanthus roseus on enzymic activities in streptozotocin induced diabetic rats. Journal of Ethno-pharmacology, 76 (2001): 269-277

Suryo. $1995 . \quad$ Sitogenetika. Yogyakarta: Gadjah Mada University Press. 